\title{
O Brasil por Frederick Douglass: impressões sobre escravidão e relações raciais no Império $^{1}$
}

\author{
LUCIANA DA CRUZ BRITO ${ }^{I}$
}

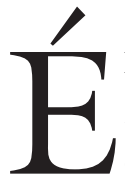

FASCINANTE a história do abolicionista negro estadunidense Frederick Douglass. Nascido no estado de Maryland na condição de escravo, assim como toda a sua família materna, Douglass afirma na sua primeira autobiografia que não sabia ao certo sua idade, mas que ouviu seu senhor dizer que tinha cerca de 17 anos em 1835. Mais tarde, pesquisas revelaram que a data do seu nascimento foi o mês de fevereiro de 1818. Somente aos 20 anos que aquele que seria a maior referência do movimento abolicionista internacional tornar-se-ia um homem livre, quando fugiu para o norte dos Estados Unidos em busca da liberdade. Dois anos depois, Douglass iniciaria uma longa carreira internacional no movimento abolicionista, que só terminaria em 1895, ano da sua morte.

Depois que se tornou um homem livre, Douglass foi editor, orador, palestrante, escritor, diplomata e articulista político. Foi autor de três biografias, uma escrita em 1845, outra em 1855, e a última em 1881. Nas suas obras, podemos observar que Douglass se reinventou, criou uma personalidade e escreveu sua própria história, escolhendo marcos importantes que estavam entrelaçados com a luta pelo fim da escravidão (Santos, 2014). Estrategicamente, os marcos histórico-pessoais escolhidos por Douglass tinham objetivos bem definidos, que eram demonstrar, inclusive para o público branco, os horrores da escravidão, que degenerava escravos e senhores, além de outras contradições do sistema escravista, como exemplo, a crueldade dos senhores de escravos, que eram cristãos.

Sua segunda autobiografia, My boundage and my freedom, escrita em 1855, é aquela que mais utilizaremos neste texto, pois essa obra reflete as preocupações do autor e o cenário politico dos Estados Unidos na década de 1850. Nesse período, Douglass estava atento à expansão do poder escravista nos Estados Unidos, com a cidadania dos negros estadunidenses livres e em negar os projetos de imigração dos afro-americanos para regiões supostamente menos preconceituosas das Américas, notadamente localizadas no Caribe e na América do Sul. Essa é um obra em que Douglass, por sua narrativa, humaniza a experiência das pessoas negras, respondendo ao racismo científico da época, cujas teses interessavam muito aos senhores de escravos e até mesmo a alguns defensores da abolição. ${ }^{2}$ Isso porque as tais teses científicas negavam a humanidade de africanos, justificando assim a escravização e/ou a segregação racial. 
A referida biografia foi escolhida em 1883 pelo jornal abolicionista Gazeta da Tarde para ser traduzida e conhecida pelo público brasileiro. Àquela altura, o Brasil amargava junto a Cuba a posição de últimos países escravistas das Américas, o que era sinônimo de atraso e algo antagônico à civilização. Com o intuito de demonstrar e convencer seus leitores da imoralidade da escravidão, Patrocínio, então proprietário do jornal, tratou de adotar o modelo bem-sucedido estadunidense de propaganda abolicionista, que era a publicação das narrativas escravas.

Assim, no dia 25 de abril de 1883, "Frederico Douglass" recebeu uma versão "brasileira" do seu nome e ficaria conhecido pelo público do Império. Sua autobiografia foi traduzida aos poucos, em diversas edições, o que durou até o mês de maio daquele mesmo ano. Douglass seria descrito pelo jornal como um homem privilegiado, dada a sua capacidade de elevar-se. Comparado a uma águia, feita para "pairar nas regiões altas", Douglass foi apresentado como alguém heroico e grande. A trajetória política desse abolicionista negro não seria descrita de forma menos pomposa: "um escritor de mérito, orador veemente e mais acérrimo defensor da sua raça". Por fim, a apresentação do abolicionista é concluída da seguinte forma:

Amanhã Frederico Douglass começará a ser reconhecido devidamente por aqueles que se interessam por uma raça desprezada e diariamente insultada por energúmenos, que trabalham para deitar por terra a propaganda em bem da causa dos oprimidos, mas que não conseguem destruir os vestígios luminosos que deixam após si homens que, como Douglass, um simples escravo, tornam-se governadores da terra onde viram a luz ainda envoltos nas trevas do cativeiro. É que a natureza os privilegia no nascedouro. ${ }^{3}$

Neste artigo, veremos que não foi somente a personalidade de Douglass que seria apropriada por negros da diáspora, como os abolicionistas afro-brasileiros. Em sintonia com a circularidade de ideias e debates em curso no século XIX, Douglass também buscaria referências em outras regiões das Américas a respeito das condições do cativeiro e da liberdade das pessoas negras, bem como do convívio entre negros e brancos. Romantizando as relações raciais em outros países e projetando as aspirações da agenda abolicionista negra estadunidense, esse abolicionista utilizou o exemplo do Brasil, de Cuba, do Haiti e até mesmo da Inglaterra para demonstrar que a sociedade multirracial tão sonhada por ele era possível.

Segundo a historiadora Juliet Hooker (2017, p.26), podemos perceber a dimensão hemisférica do pensamento de Frederick Douglass a partir da sua análise sobre as relações raciais na América Latina. É pela sua leitura das relações raciais e o cativeiro naquela região que veremos como suas descrições se entrelaçavam com aquilo que defendia para seu próprio país: o convívio harmonioso entre negros e brancos, a valorização intelectual e moral do homem negro, o acesso à cidadania, ou seja, o direito ao voto e o fim de impedimentos legais de qualquer natureza que fosse baseado na cor da pele, além do fim da escravidão. 


\section{GAZETA DA TARDE}

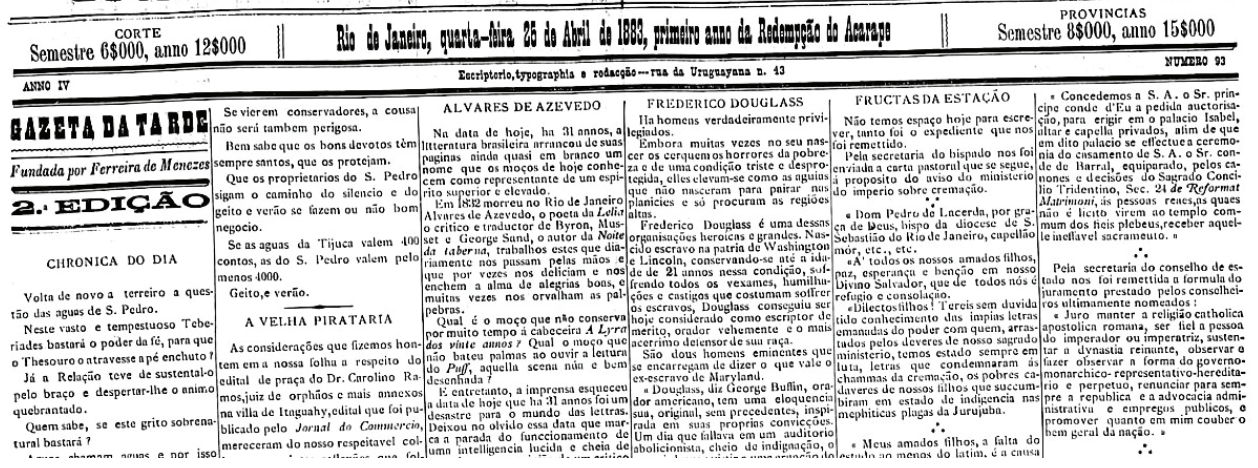

Jornal Gazeta da Tarde.

Os textos em que Douglass faz referências à América do Sul, encontrados nos seus artigos publicados em jornais e discursos, geralmente não são encontrados nas suas biografias, o que faz que, também segundo Hooker, muitos dos seus biógrafos percam a dimensão transnacional do pensamento desse abolicionista (ibidem, p.27-8). Seria nos artigos publicados nos jornais e nos discursos que Douglass faria associações entre as condições de vida dos afro-estadunidenses e dos afro-latinos. Encontramos o mesmo padrão para o Brasil, uma vez que nenhuma menção sobre o país é feita nas suas autobiografias, ao contrário do que encontramos em suas falas e textos jornalísticos. Segundo Nwankwo, pesquisadora que também analisou a transnacionalidade da escrita de Douglass com base nas suas autobiografias, essa escolha do abolicionista tem muito a ver com as estratégias desse gênero literário. A isso a autora chama de "negritude binária”, que seria a opção de abolicionistas escritores como Douglass, preferirem ficar restritos ao contexto nacional. Além do mais, as biografias seriam dirigidas aos afro-americanos e não à diáspora. No entanto, a própria publicação de uma das suas biografias num jornal brasileiro mostra como essas obras poderiam tomar um alcance maior (Nwankwo, 2005, p.132,133,145).

Interpretamos as escolhas de Douglass da seguinte forma: nas biografias, que também eram influenciadas por editores, optava-se pelo padrão desse tipo de narrativa, que era a do homem que superou desafios e depois de tornou um cidadão excepcional. Nesse sentido, citar nas biografias outros exemplos de pessoas negras de outras partes da diáspora poderia deslocar a atenção da personalidade do autor. Além disso, a autobiografia de ex-escravos tentava provocar também a empatia de pessoas brancas, na intenção de sensibilizá-las contra os horrores da escravidão. Se a condição racial os diferenciava, em comum, Douglass e o público branco compartilhavam o fato de serem todos estadunidenses, e o abolicionista tentava mobilizar sentimentos de empatia e pertencimento nacional ao longo do seu texto. No entanto, isso não o impedia de tecer duras crí- 


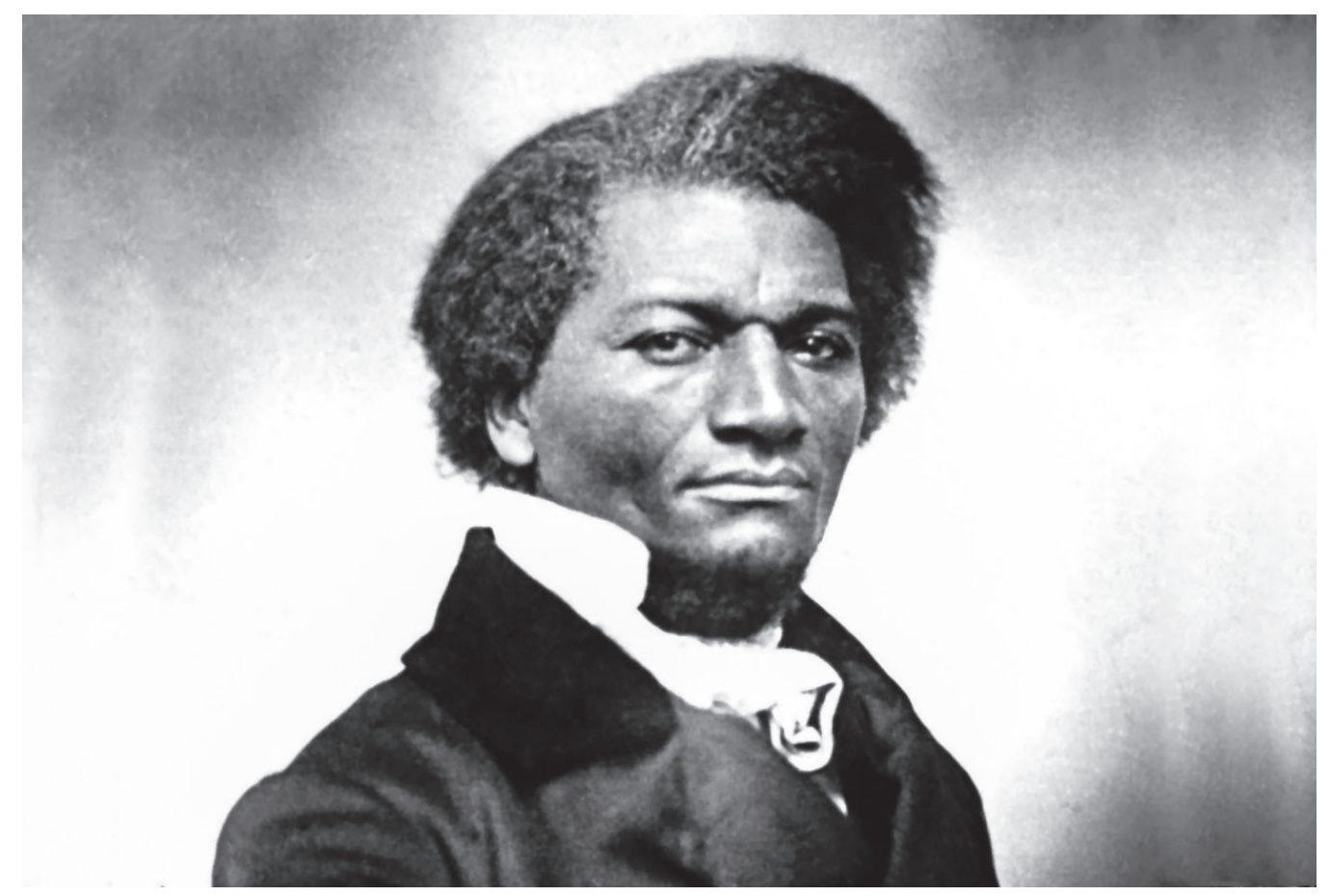

Frederick Douglass (1818-1895).

ticas ao país que nasceu: “eu não pertenço a nenhuma nação”, chegou a declarar em My boundage and my freedom (Douglass, 2014, p.295).

É possível também citar que outras nações escravistas, como o Brasil, poderia dar a impressão de que a região Norte dos Estados Unidos, que era também alvo das críticas de Douglass, era uma região avançada e mais progressista, uma vez que já havia decretado a abolição desde as primeiras décadas do século XIX. Isso comprometeria o discurso de Douglass que denunciava constantemente o preconceito racial naquela região. Concordamos com Nwankwo (205, p.147)) quando afirma que, nos jornais, Douglass poderia se deslocar da sua imagem individual de estadunidense e explorar sua identidade afroatlântica.De fato, esse abolicionista explorou isso muito bem: citou o Haiti para falar da bravura dos homens negros como soldados e de Toussaint como governante. Ele mencionou também o conforto com que ele próprio e outros negros ingleses eram aceitos em Londres e falou em diversos momentos da integração racial supostamente vigente nos países latino-americanos. Discutiremos como Douglass apropriou-se da e descreveu a experiência da população negra brasileira, escravizada e liberta, para responder às suas demandas políticas nos Estados Unidos.

Utilizando o exemplo do Brasil, Douglass questionou a ciência estadunidense que afirmava a inferioridade racial, bem como a impossibilidade de que raças distintas convivessem numa sociedade de forma harmônica e em igualdade de condições. Foi com o exemplo brasileiro que também defendeu a capacidade intelectual dos indivíduos de origem mista, chamados de híbridos ou mulatos, e 
questionou moralmente a sociedade apontando as contradições do cristianismo protestante ante o catolicismo, bem como a República diante da monarquia. A crença na superioridade dos Estados Unidos como nação e o suposto atraso do Brasil monárquico, escravista e católico também eram aspectos relativizados. $\mathrm{O}$ avanço das leis escravistas estadunidenses era confrontado pela cidadania concedida aos libertos brasileiros, manifestada no direito ao voto, no acesso a cargos públicos, inclusive no exército e no governo, e dentre outras coisas, na ausência de leis que impedissem o casamento inter-racial. Assim, Douglass projetava um cenário que caracterizava o Império brasileiro como local mais favorável para a população negra, mas sem defender a imigração para aquele país.

Para compreender essas interpretações de Douglass sobre o Brasil escravista, nação que chegou a descrever como um país onde os negros tinham acesso a tudo, analisaremos sua biografia, sobretudo aquela escrita em 1855, My boundage and my freedom. Examinaremos também o que ele escreveu sobre o Brasil em seus artigos e nos seus discursos proferidos em diversos eventos abolicionistas. Alguns temas mais recorrentes nos chamam particularmente a atenção, como a mistura racial e a condição da população liberta brasileira. Assim, buscaremos entender o jogo de apropriações, romanização e projeções, bem como as estratégias narrativas utilizadas por Douglass, que fez uso do exemplo brasileiro para, na década de 1850 e ao longo dos anos 1860, responder aos obstáculos impostos nos Estados Unidos para a concretização do seu sonho, que era fazer do seu país uma sociedade multirracial e igualitária.

\section{Índio não, negro! Identidade, ciência e abolicionismo no pensamento de Frederick Douglass}

Em um dos seus discursos num evento abolicionista, dessa vez no ano de 1862, portanto durante a Guerra Civil, Frederick Douglass utilizou uma frequente estratégia que era ridicularizar o racismo estadunidense, arrancando risos da plateia.

Douglass contou que certo dia foi abordado por um homem branco desconhecido, que lhe disse: "Olá, está vindo de longe hein?". O tal estranho, diante do silêncio daquele homem não branco, insistiu: "está vindo de longe, hein, índio?”. A resposta de Douglass foi imediata: “(índio) não, nigger" . Ainda segundo o abolicionista, o fato de ser um enigma para o estranho branco, que provavelmente se sentia capaz de identificar negros e indígenas, fez que ele, segundo o abolicionista: "caísse para trás, como se tivesse tomado um tiro". ${ }^{5}$ Douglass naquele momento, não só ridicularizava a sociedade branca estadunidense e as teses científicas das décadas de 1840 e 1850, mas também ironizava um dos seus maiores dilemas pessoais: o fato de ser um homem negro que também trazia traços físicos que, por vezes, o colocava em situações e questionamentos muito peculiares.

Ao longo da sua vida, sua filiação sempre foi rodeada de mistérios e especulações. Isso não somente pelas suas características físicas, mas também quando 
se especulava sobre a origem da sua aversão pelo cativeiro e do seu amor pelas letras. Na sua primeira autobiografia, escrita em 1845, Douglass (2000, p.1-2) descreve sua mãe como "de cor escura, mais escura que meu avô e minha avó". Já o pai é simplesmente definido como "um homem branco... isso é tudo que ouvi dizer sobre meu lado paterno". Douglass também afirmou, "por ouvir dizer", que seu pai era seu próprio senhor.

$\mathrm{Na}$ sua segunda biografia, escrita em 1855, Douglass (2014) se permite descrever um pouco mais as características da sua mãe: "ela era alta, e finamente proporcional... tinha a pele bem escura e brilhante, traços regulares, e comparada aos outros escravos, ela tinha comportamento muito calmo". Douglass ainda chegou a afirmar que, na falta de uma fotografia da sua mãe, sempre recorria a imagem presente no livro de James Cowles, Prichard, "The natural history of man", que tinha uma figura, cujas características lembravam muito sua mãe. Não por acaso, a imagem escolhida por Douglass seria do faraó Ramses VII, cujos traços contrastavam com aqueles atribuídos pelos cientistas aos africanos. Segundo os poligenistas, a animalidade dos africanos poderia ser percebida pelo tamanho dos seus lábios, braços, pés, tamanho de crânio, e no caso das mulheres, pelo comportamento sexual desenfreado, enfim características que diferiam totalmente dos "modos calmos" de Harriet Bailey, mãe de Frederick Douglass.

A obra mencionada por Douglass, The natural history of man, escrita pelo cientista inglês James Prichard (1855)), defendia basicamente as teses poligenistas muito em voga no meio científico dos Estados Unidos desde a década de 1840. Publicada pela primeira vez em 1813, e recebendo diversas edições ao longo do século XIX (aparentemente, Douglass leu a edição de 1855), a obra demonstrava ambiguidade a respeito do tipo egípcio, se caucasiano ou negro, mas apontava uma variedade racial na região. Prichard preferia não afirmar nada definitivo sobre a raça dos egípcios, mas retratar a realeza com características caucasianas. Outras informações, também contidas na obra, devem ter arrancado a atenção de Douglass, que era a longa discussão sobre os afeitos da mistura racial. Para Prichard, os mulatos como Douglass, eram resultado de duas raças distintas, uma superior e outra inferior (ibidem, p.19).

Assim, as referências científicas, que eram fontes dos seus próprios estudos sobre raça, humanidade e diferenças raciais, não diziam nada favorável sobre sua própria ancestralidade africana, ou até mesmo sua condição de "mulato". Diversos foram os episódios em que, a despeito da sua condição por vezes ambígua, Douglass afirmou-se negro, atribuindo suas qualidades positivas ao lado materno. Sobre seu genitor, Douglass $(2014$, p.43) afirmava não dizer nada sobre seu pai, figura, segundo ele, "envolta em um mistério que eu nunca poderei penetrar".

Ainda em My boundage and my freedom, a questão da origem birracial de Douglass e as especulações sobre as influências heranças genéticas transmitidas pelo seu lado "negro ou branco" foram discutidas pelo seu amigo, o abolicio- 
Douglass ouviu dizer que seu pai era seu próprio senhor.

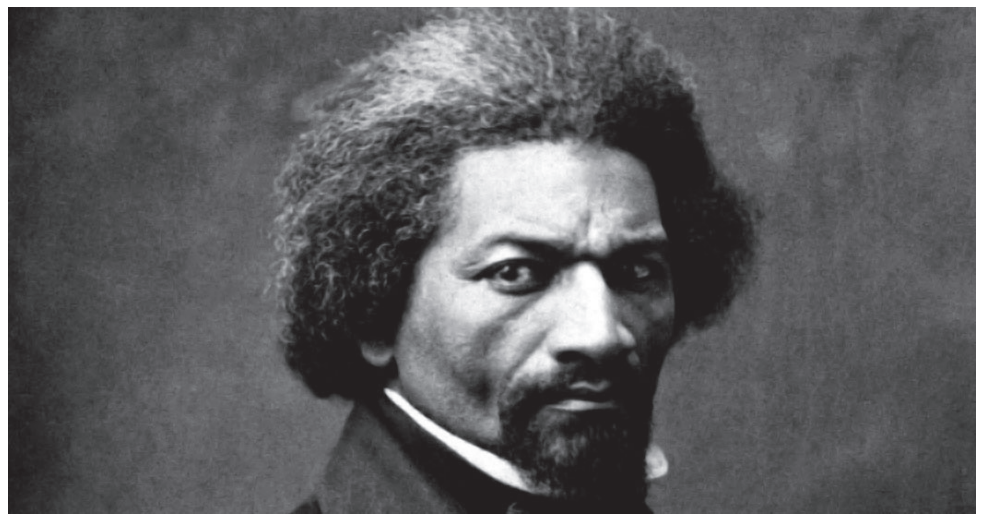

marked. How admirably, also, are they seen in the subjoined juvenile head (fig. 49), which is that of a royal prince, copied from the very ancient paintings in the tomb of Pehrai at Eletheias; and also the face of Rameses VII. (fig. 50), who lived, perhaps, 1000 years later in time.
Fre. 49.

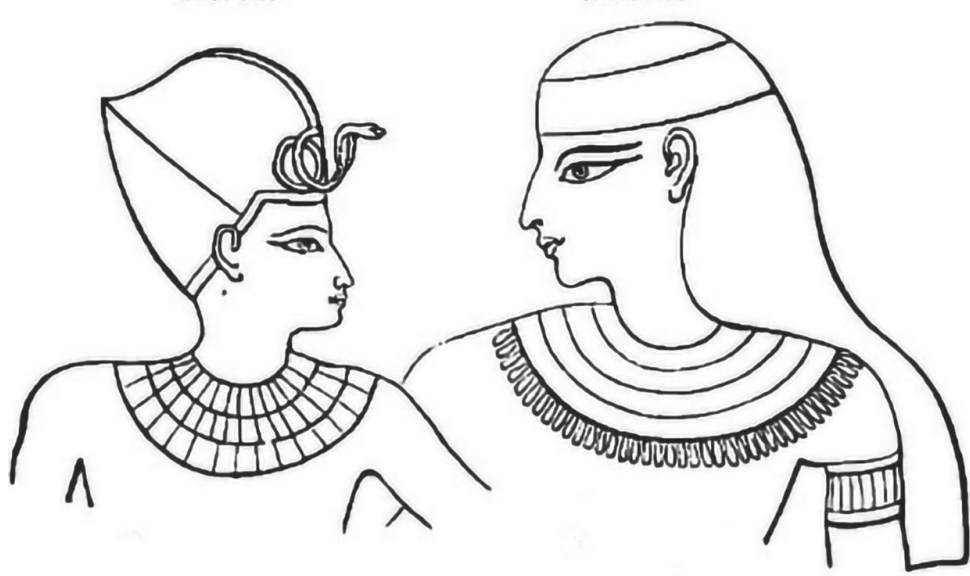

"I observe that the priests almost invariably present this
- Theee refor to platee in Dr. Morton'e paper.

nista negro James McCune Smith, que escreveu o prefácio da obra. Após elogiar o estilo da escrita e a oratória de Douglass, o que chamou de habilidades "mais marcantes e fenomenais" do abolicionista, comparando-o aos clássicos da língua inglesa, Smith chegou a refletir sobre qual seria a origem da capacidade intelectual de Douglass (ibidem, p.23). A resposta a essa questão viria do próprio Douglass;

Eu estou disposto, e mesmo feliz, de atribuir meu amor pelas letras, a despeito de todo preconceito, não à minha admitida paternidade anglo-saxã, mas à genialidade da minha mãe, negra, desprotegida e inculta, uma mulher que pertenceu a uma raça cujas capacidades intelectuais, no presente é comum serem descreditadas. (ibidem, p.48-9) 
Para James McCune Smith, o efeito da mistura racial sobre Douglass era o efeito da mistura do sangue branco com o "bom sangue negro", positivando assim a mistura racial, que a ciência da época condenava. Já Douglass entendia a mistura racial como um dos aspectos degeneradores da escravidão, que destruiu famílias e fazia que escravos, inclusive os mais escuros, fossem escravizados pelos seus próprios pais, que carregavam em si "a glória da pureza do seu sangue anglo-saxão" (ibidem, p.49).

Portanto, percebemos que entre os abolicionistas negros como Douglass, a mistura racial nos Estados Unidos era uma demonstração dos males da escravidão, das contradições dos senhores de escravos cristãos e da licenciosidade vigente na sociedade escravista. A mulher escravizada era deixada vulnerável à exploração sexual, à violência de uma senhora vingativa e, além de tudo, não tinha nenhum poder sobre seus filhos. Segundo Douglass, não havia nada debaixo do céu que fosse o maior inimigo da afeição familiar do que a escravidão (ibidem, p.50).

Contudo, veremos algo muito interessante na narrativa de Douglass sobre a mistura racial quando o contexto é deslocado para outras partes da América. Suas interpretações e projeções sobre a integração social, habilidades intelectuais e condições da vida dos dito mulatos, quando na América Latina e no Caribe, eram utilizadas para afirmar a excepcionalidade do racismo estadunidense. Esse ponto de vista não era comentado nas narrativas, pois, como afirma James McCune Smith na introdução de My boundage and my freedom, aquele seria "um livro americano, para americanos, no completo sentido da ideia" (ibidem, p.25). ${ }^{6}$

Exemplos dos feitos de indivíduos de origem birracial seriam respostas ao racismo científico dos anos 1840 e 1850 , sobretudo às teses poligenistas. O poligenismo acreditava que, além daquela criação bíblica que a única criação era aquela cuja humanidade descendia de Adão e Eva, houve outras criações, em diversas partes do globo, o que gerou diversas raças em diferentes estágios de desenvolvimento (Fredickson, 1971, p.78-81). ${ }^{7}$ Assim, para Douglass, era muito importante rebater essas teses buscando exemplos vivos que as questionassem teorias, como o hibridismo, que afirmassem a inferioridade de pessoas que, como ele, eram resultado de relações entre pessoas de "raças distintas".

Um dos maiores teóricos do hibridismo era o médico do Alabama, Josiah Nott. Membro da Escola Americana de Etnologia, em 1844, Nott publicou um artigo chamado "Caucasian and negro races", no qual ele defendia a supremacia branca e afirmava que a mistura racial comprometia essa supremacia, o que ameaçava a própria existência da população branca. Até mesmo a suposta inteligência dos mulatos, maior do que as dos negros "puros", segundo Nott, constituía-se num problema. Isso porque a herança biológica do ancestral branco geraria um indivíduo insubmisso, que rejeitava a condição de escravo, tornando-o perigoso ao sistema e potencialmente um líder de insurreições (Fredrickson, 1971, p.7881; Brito, 2014, p.28-32). 
Josiah Nott também utilizou a América Latina como observatório das suas hipóteses e projeções. Para o médico, o maior exemplo dos efeitos da mistura racial poderiam ser vistos em Nova Orleans e na América Latina. Isso porque ele acreditava que, nessas regiões, a mistura racial era praticada sem controle e sem uma política de segregação, o que permitia que os mulatos não só vivessem integrados à sociedade, mas, muitas vezes, vivessem ou se passassem por brancos (Nott, 1846, p.1). ${ }^{8}$

Ao tomar conhecimento dessas ideias, que circulavam desde a década de 1840 e foram sendo reafirmadas ao longo dos anos 1850 e 1860, Douglass se apropriava delas e fazia suas próprias releituras. Longe de parecer algo degenerativo e negativo, a notícia da ampla prática de mistura racial em países latino-americanos apareceu para Douglass como os exemplos que ele precisava para refutar tais teses. A dinâmica racial de México, Venezuela, Nicarágua, Haiti, Cuba e sobretudo Brasil fazia o abolicionista crer que a sociedade multirracial que ele tanto acreditava era possível. Vejamos como essa crença foi um argumento incorporado ao discurso abolicionista de Frederick Douglass.

\section{Cidadania em terras alheias: olhares sobre raça na outra América}

Sobre seu período na Inglaterra, Frederick Douglass chegou a escrever que estava vivendo "os momentos mais felizes da sua vida". Essa "nova vida" que estava vivendo era justificada pelo seu sentimento de inserção e aceitação social, o que era possível pela ausência de leis segregacionistas naquele país. Portanto, ele afirmava que estava sendo tratado de forma hospitaleira, numa sociedade marcada pelo espírito de liberdade e com a "completa ausência de qualquer coisa que se parecesse com preconceito contra mim, por conta da cor da minha pele, contrastando com minha longa e amarga experiência nos Estados Unidos (Douglass, 2014, p.296).

A partir de então, Douglass passaria a utilizar uma constante estratégia, que era apontar o preconceito de cor nos Estados Unidos como se fosse algo muito particular daquele país, não existente em nenhum outro. Douglass ainda narrou que acessou transporte público e sentou-se ao lado de pessoa brancas, hospedou-se em hotéis, entrou em restaurantes e igrejas e em nenhum desses locais ouviu a conhecida frase: "nós não aceitamos niggers aqui" (ibidem, p.2967).

A partir da experiência fora do seu próprio país, Douglass passou a acreditar que era possível existir uma sociedade multirracial. A questão agora era entender se isso seria possível em sociedades escravistas americanas, ou se o preconceito tal qual nos Estados Unidos era comum a todas elas. Após dois anos na Europa, depois de ter levantado recursos para fundar o seu primeiro jornal, o The North Star, em 1847, Douglass passou a analisar o preconceito racial e a escravidão nos Estados Unidos à luz do que acontecia no restante do mundo, sobretudo em outras nações escravistas americanas. 
É importante também reconhecer que tal visão global da experiência negra não era uma particularidade de Frederick Douglass. Desde o início dos anos 1840, os jornais da imprensa negra abolicionista estadunidense já traziam notícias recebidas de outras nações americanas, que ainda que fossem escravistas, demonstravam que era possível um convívio harmônico entre negros e brancos, e que os libertos eram capazes de contribuir na sociedade, intelectual e moralmente. Esses exemplos de sociedades multirraciais, ainda que superdimensionados, se encaixariam no modelos de sociedade que boa parte dos abolicionistas negros reivindicavam, onde pessoas de diversas origens conviveriam e tinham um lugar social. Isso contrariava até mesmo muitos membros do movimento abolicionista branco, que não acreditavam ser possível um convívio entre as raças negras e branca nos Estados Unidos (Brito, 2014, p.70-2).

Ainda de acordo com a historiadora Juliet Hooker (2017, p.26, 38-9), é a partir da análise do abolicionista sobre esses outros países que podemos perceber a dimensão hemisférica do seu pensamento. As descrições das relações raciais na Nicarágua, em Moskito Kingdom (localizado entre a costa da Nicarágua e Honduras), Haiti, Cuba e no Brasil pareciam-lhe constituir em espaços de liberdade, que eram referências de cidadania, que significava para Douglass igualdade de oportunidades a despeito da cor da pele. As revoltas escravas ocorridas no Caribe eram exemplos de bravura das populações negras daqueles países. A autonomia política dos ex-escravos eram percebidas em relações raciais mais igualitárias, em que, incluindo os mulatos, cuja ciência enfatizava a degeneração racial, estavam atuantes e inseridos socialmente, inclusive como líderes dessas nações (ibidem, p.39-42, 45-6).

Podemos afirmar que o exemplo do Haiti era o mais importante e emblemático para os abolicionistas negros estadunidenses, inclusive para Douglass. Diante das já apontadas teses científicas que afirmavam a incapacidade intelectual e militar dos africanos e seus descendentes, o exemplo de heroísmo do Haiti parecia ser importante e estratégico para questionar tais teses. O Haiti tinha um exemplo em particular, além de os negros serem livres, após uma revolta da qual saíram vitoriosos, o país era governado por negros (ibidem, p.45). A historiadora Leslie Alexander afirma que, sobretudo para as pessoas negras da região Norte dos Estados Unidos, o Haiti era a prova de que a liberdade não era uma ilusão. Desde a década de 1830, negros estadunidenses livres e libertos estivessem dispostos a imigrar para aquele país, o que era incentivado por diversos setores da sociedade, incluindo abolicionistas negros, mas não Frederick Douglass (Alexander, 2010, p.57-8).

No caso do Brasil, país que era escravista, monárquico e católico, e que portanto agregava todos os símbolos que colocavam o país numa situação de atraso em relação aos Estados Unidos, inclusive para Frederick Douglass, o ponto positivo desse país eram as relações raciais. Ao que parece, esse abolicionista nunca visitou o Império, portanto as fontes de informações que utilizou para conhecer o Brasil eram notícias de viajantes publicadas em livros e jornais e teses 
científicas também disseminadas nesse tipo de mídia. Tanto em jornais escravistas do Sul quanto em jornais que circulavam no Norte, alguns deles abolicionistas, como o The National Era, o Brasil era frequentemente citado. No caso dos jornais escravistas, atentos às possibilidades e interesses de expansão para a América Latina, o Brasil interessava pela natureza e pelas possibilidades de negócios, sobretudo ligados à escravidão. Em todos eles, escravistas ou abolicionistas, o objeto de estranhamento era sempre o mesmo: a intrigante forma com que negros e brancos se relacionavam no Império.

\section{O Império do Brasil: onde os negros têm acesso a tudo}

Vejamos como o Brasil era apresentado no artigo "The brazilians", publicado no mês de abril do ano de 1849 no jornal Quaker Friend's Review, da Filadélfia. Já nas primeiras linhas, os brasileiros eram descritos como "um povo peculiar", cujo sistema político era monárquico mas funcionava como se fosse uma República. Sobre a população brasileira, as relações raciais e a inserção dos mulatos na sociedade, era dito o seguinte:

Dos sete milhões que constituem a população total do Brasil, estima-se que três milhões são escravos negros, dois milhões e meio são índios aborígines e negros livres, e o resíduo, um milhão e meio, são brancos. O estado social da população brasileira não é marcado pela distinção de cor, tão imperativa em outro país na produção de classes. No Brasil só existe distinção entre liberdade e servidão. Os negros tem acesso a tudo, e estão em posse de muitos cargos de honra e confiança, e engajados em todos os departamentos de negócios. A raça branca e a negra se encontram em termos de perfeita igualdade no intercurso social, e casam-se entre si sem escrúpulos...o escritor do (jornal) North American Review...conheceu "a esposa de um almirante, cuja pele era a mais escura entre as filhas da África" e menciona "o desalento de um agente diplomático americano, com a entrada de um coronel negro na corte, a quem ele foi apresentado". Nós temos a mesma notícia do fato que, não faz muito tempo, o embaixador brasileiro na Inglaterra era um mulato, e no presente momento, uma ampla maioria dos membros do exército, tal como os oficiais, são descendentes de africanos. ${ }^{9}$

$\mathrm{O}$ trecho transcrito aqui tocava em vários pontos muito caros à sociedade estadunidense no final da década de 1840 e ao longo da década de 1850. No presente fragmento, temas como teses científicas sobre hibridismo e capacidade intelectual de negros e mulatos, mistura racial, a posição social de mulheres e homens negros, enfim assuntos que geravam intensos debates entre escravistas e abolicionistas, estavam presentes. Sendo um jornal da região Norte, que não era mais escravista, mas onde as regras de segregação racial garantiam que negros e brancos estivessem longe de ocupar um lugar social de igualdade, a realidade brasileira não deve deixar de ter chocado o observador, autor do registro. Não sabemos ao certo a autoria do texto, mas o fato é que matérias como essa eram replicadas em diversos jornais, tanto escravistas quanto abolicionistas negros. Douglass não perderia essa oportunidade e não fez diferente. Aproveitou o conteúdo da matéria, apropriou-se do texto de forma bem estratégica e também 
republicou o mesmo trecho no seu jornal, o The North Star, na edição de 13 de julho de 1849, ou seja, poucos meses depois da publicação de abril do jornal The Friend's Review. Na sua publicação, Douglass só alterou o título da matéria, cujo título original "The brazilians", foi substituído no jornal abolicionista negro por "Blacks in Brazil".

Para entender o contexto e o impacto das notícias do Brasil no final dos anos 40 e anos 50 do século XIX nos Estados Unidos, é importante lembrar que as notícias acima iam contra a ideia de que pureza racial era algo definidor do sucesso de uma nação. Do mesmo modo, a mistura racial, como vimos com Josiah Nott, significava o fracasso, a degeneração do sangue caucasiano. Assim, relações raciais ilegítimas (pela natureza) eram uma ameaça à nação americana (Fredrickson, 1971, p.48-9).Se a notícia sobre os negros e mulatos do Brasil, que faziam parte do Império como livres e libertos, tinham acesso a tudo, Douglass viu aí uma excelente oportunidade de questionar a ciência e provar as capacidades desses, demonstrando também ser completamente possível aquilo que acreditava, que era um sociedade multirracial, onde negros e brancos conviviam harmonicamente. Assim, a releitura do abolicionista sobre o Brasil era positiva e dialogava com duas estratégias utilizadas por ele, e outros abolicionistas negros, na década de 1840 e 1850: enfatizar o excepcionalismo do racismo norte-americano e buscar o exemplo de outras comunidades negras bem sucedidas em outras partes do que hoje chamamos de diáspora. ${ }^{10}$

Um aspecto muito importante no texto é a mensagem sobre mistura racial, apropriada por Douglass, inclusive para falar do racismo vigente na região Norte. Nesse sentido, o tal embaixador brasileiro na Inglaterra era um mulato, citado no artigo "The brazilians", ou "Blacks in Brazil", cumpre um papel importante e é cheio de significados e intenções políticas. Ao que parece, o tal embaixador era o diplomata carioca Joaquim Tomás do Amaral, ou visconde de Cabo Frio, que estava à frente das relações entre o Império brasileiro e a Inglaterra entre 1845 e $1854 .{ }^{11} \mathrm{~A}$ única imagem que encontramos do diplomata nos dá uma ideia de imprecisão: poderia facilmente ser visto como mulato para o olhar de um observador estadunidense, porém nacionalmente ser considerado um homem branco, membro das elites do Império do Brasil.

Desde a Revolução Americana (1776), a identidade nacional dos Estados Unidos foi pensada e sustentada nas bases da pureza racial, onde o (puro) homem branco, descendente de inglês, era a representação da cidadania no país (Brito, 2016, p.108). ${ }^{12}$ Negros, indígenas e até mesmo pessoas de origem mista estariam fora do projeto de nação no lugar de cidadãos e cidadãs, o que fazia que, desde os século XVIII, as primeiras leis proibindo relações inter-raciais começassem a serem implementadas para acabar com o lugar intermediário reivindicado por algumas pessoas não brancas. Nos estados do Norte, por exemplo, as mesmas leis que proibiam o casamento inter-racial no período escravista continuaram valendo no pós-abolição, como é o caso de Massachusetts e Rhode Island (Lemire, 2002, p.4, 57). 
Além disso, o conceito de amalgamação tinha um significado mais amplo do que no Brasil, incluindo várias práticas cotidianas que não somente o intercurso sexual entre negros e brancos. O termo era originalmente empregado na metalurgia e significava a mistura de metais distintos, daí a analogia com a mistura de "sangues distintos". Assim, nos Estados Unidos, sobretudo na região Norte, alguém poderia ser acusada ou acusado de praticar amalgamação caso simplesmente estivesse interagindo ou compartilhando um espaço com uma pessoa negra, numa condição em que essa última não estivesse na condição de serviçal ou escravo, em seja, em termos de igualdade. Tal prática significava uma grave inversão das normas da sociedade estadunidense e, por esse motivo, a prática da amalgamação motivou muitas revoltas, violência e motins (Lemire, 2002, p.88; Brito, 2014, p.89).

Naquele mesmo ano de 1849, alguns meses antes da publicação do artigo "Blacks in Brazil" no seu jornal, o próprio Douglass havia sido vítima novamente de mais um episódio de violência motivado pela amalgamação. $\mathrm{O}$ ato cometido pelo abolicionista foi visto como uma quebra de regras raciais e violação de mulheres brancas, de acordo com os homens brancos que o atacaram. No mês de maio, Douglass passeava pelas ruas de Nova York de braços entrelaçados com duas amigas brancas, as irmãs abolicionistas Julia e Eliza Griffiths, quando foi atacado por uma turba. O grupo justificou o ataque argumentando que o abolicionista havia violado regras de decoro moral com uma ato "audacioso e desgraçado", cometendo um abuso contra o país, a constituição e seus cidadãos. O episódio é citado na obra recente do historiador David Blight, que procura investigar as dimensões políticas e pessoais da vida de Douglass. Blight entende que esse episódio provocou uma importante reflexão do abolicionista sobre racismo nos Estados Unidos no século XIX. ${ }^{13}$

Depois desse ocorrido, Douglass havia afirmado que "preconceito" seria uma palavra muito fraca e até inocente para descrever o sentimento dos brancos contra os negros no seu país. Segundo ele, a palavra mais apropriada seria "um ódio infernal" dirigido aos homens negros. Portanto, concluía ele, o problema não era o convívio entre homens negros e mulheres brancas, uma vez que senhoras conviviam com escravos que lhe serviam no sul escravista. O problema, então, que motivaria ódio e rejeição, seria a igualdade racial, e não necessariamente a cor da pele (Blight, 2018, p.204-5). Ao tomar notícias do Brasil dois meses depois desse ocorrido, Douglass certamente pensou que se fosse no Império brasileiro o ato de intimidade entre ele e as amigas brancas seria tratado com a maior normalidade, e não haveria despertado a ira de ninguém.

O impacto das relações inter-raciais, sobretudo quando isso envolvia sua relação com mulheres brancas, acompanharia Douglass até os seus últimos dias. Em 1883, faleceu a sua primeira esposa, Anna Murray Douglass, uma mulher negra nascida livre no estado de Maryland. No ano seguinte, Frederick se casaria novamente, dessa vez com uma mulher branca, a abolicionista e sufragista Helen 
Pitts Douglass. A relação considerada escandalosa naquela época foi justificada ironicamente por Douglass da seguinte forma: "Isso prova que sou imparcial; minha primeira esposa era da cor de minha mãe e a segunda, da cor de meu pai". ${ }^{14}$

Enquanto o próprio Douglass colecionava episódios em que foi arrancado à força de hotéis, restaurantes, trens e até mesmo de navios, sob o recusa dos passageiros brancos que não queriam compartilhar o espaço com um homem negro, no Império havia descendentes de africanos que frequentavam a corte, ocupavam cargos importantes no governo, contestando ideias de inferioridade racial e do racismo como algo intransponível. O caso do embaixador mulato em Londres confrontava as noções de degeneração racial que tanto incomodavam Douglass. Portanto, no Brasil, aparentemente os homens negros tinham sua masculinidade reconhecida e respeitada, tal qual os homens brancos. A notícia de uma mulher negra "a mais escura entre as filhas da África", que tinha o status de esposa do almirante, era o perfeito exemplo de harmonia entre as raças. $\mathrm{O}$ lugar dessa mulher, que na América latina era de cônjuge, diferia bastante da realidade das mulheres escravizadas no sul estadunidense que, como a própria mãe de Douglass, na relação com homens brancos, tinham o único papel de ser trabalhadoras escravizadas, objeto dos abusos sexuais dos seus senhores e geradoras de mulatos que engrossariam a escravaria.

Ao longo dos anos 1850, o Brasil permaneceria sendo uma referência para Douglass, sempre citado nos seus jornais para cumprir a tarefa de denunciar o preconceito racial estadunidense e reafirmar a possibilidade de existência de uma sociedade igualitária e multirracial, ainda que escravista. Embora em sua biografia houvesse afirmado que "nenhum homem de cor é realmente livre num estado escravista" (Douglass, 2014, p.278), aparentemente parecia-lhe possível que escravidão e a cidadania faziam parte da realidade brasileira, mas não da estadunidense. Comparando as possibilidades de acesso à alforria no Brasil Império e no sul estadunidense, na década de 1850, percebemos uma grande diferença. De acordo com dados coligidos por Slenes, enquanto no Rio de Janeiro o número de alforrias poderia variar entre $2,5 \%$ e $5,4 \%$ (áreas de plantation e urbana, respectivamente), nos Estados Unidos esse número não ultrapassava os $0,45 \%$. De acordo com o censo brasileiro de 1872, três quartos dos negros nascidos do Brasil eram libertos, enquanto no sul estadunidense, em 1860, às vésperas da Guerra Civil, esse número não passava dos 6\% (Slenes, 2012, p.100-18).

Portanto, os números revelam que o peso do decreto da abolição foi muito maior nos Estados Confederados do que no Império, onde no 13 de maio de 1888 a grande maioria dos negros brasileiros já era até mesmo de cidadãos, de acordo com a Constituição de 1824. Tais dados sobre alforria no Brasil, inegavelmente significantes, poderiam de fato dar a impressão aos abolicionistas negros que, ainda que escravista, os senhores de escravos do Império estavam dispostos a resolver o problema da escravidão no Brasil por livre iniciativa. 


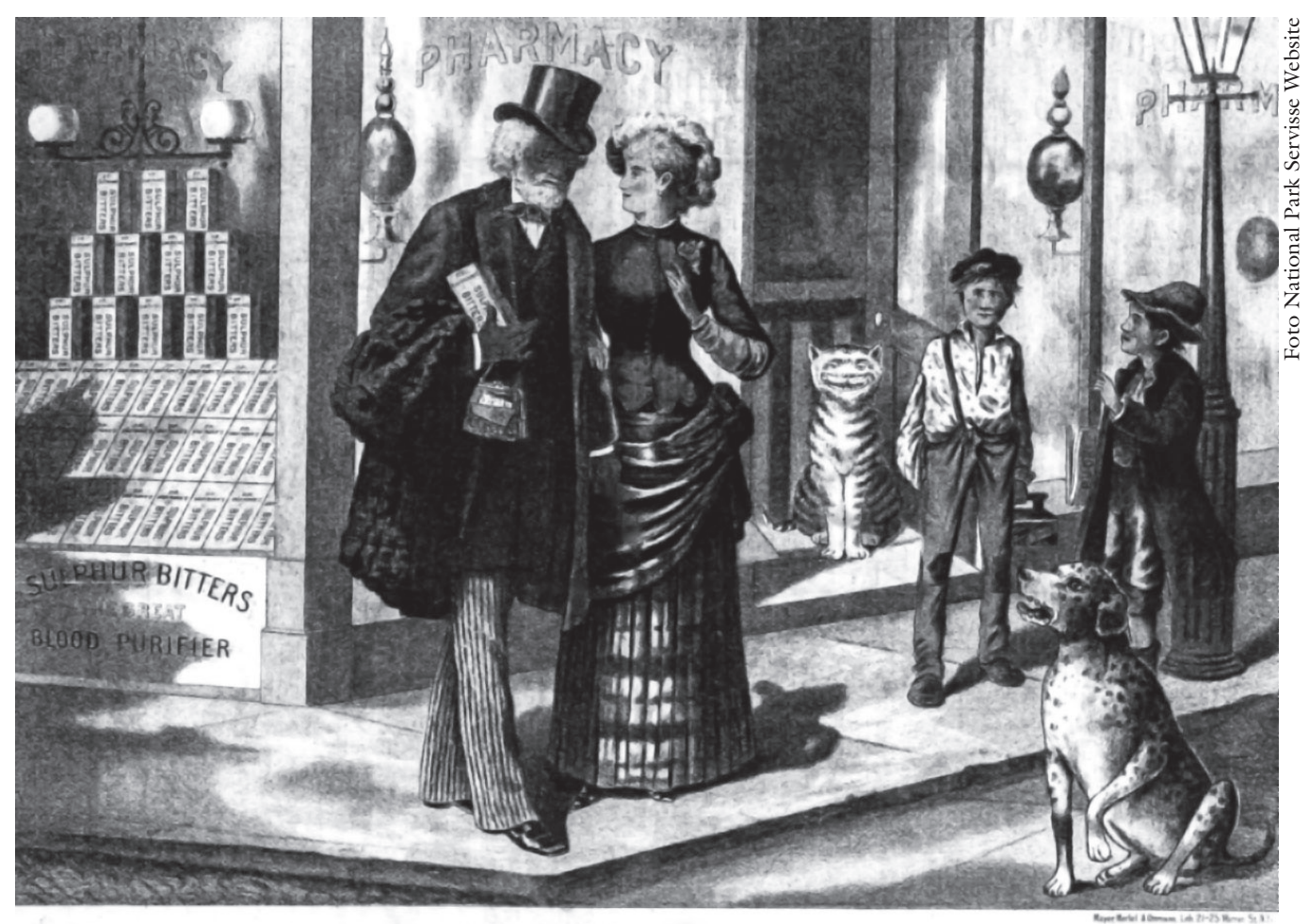

NEWS BOY HI, YI OERE JIMMY WHOSE OEM FOLKSES WHATS GOT DE SULPHUA BITTERS?

BOOT BLACK : I SPEC DATS FRED DOUGLAS ANO HIS WIFE GOLLY HE IS GOING TO TAKE DE SULPMUR BITTERS FOR MIS COMPLEXION -

A imagem é uma sátira produzida logo depois do casamento de Frederick e Hellen Douglass. O casal sai de uma farmácia e o abolicionista leva um tônico "purificador do sangue". Na legenda, um dos garotos sugere que Douglass comprou o produto para clarear a pele.

Assim, enquanto na década de 1850 o Brasil era anunciado na imprensa abolicionista negra como uma país que caminhava pacificamente para o fim da escravidão, episódios políticos importantes fizeram Douglass reforçar o tom da sua luta política naquele década devido ao fortalecimento do poder escravista, que se estendia para a região Norte. Já em 1850, foi aprovada a Fugitive Slave Law, lei pela qual qualquer cidadão (homem branco) podia capturar uma pessoa negra no norte e devolvê-la ao seu proprietário no sul. Em 1854, o Kansas Nebraska Act autorizava a expansão da escravidão para os novos estados de Kansas e Nebraska (Holt, 2010). Essas leis demonstravam os interesses escravistas de se expandir, não só em território estadunidense, mas também em território latino-americano, o que preocupava muito Douglass, como veremos.

Já nos primeiros meses do ano 1852, Frederick Douglass traria mais uma vez o Brasil para as páginas de um dos seus jornais, dessa vez o Frederick Douglass Paper. A matéria intitulada "From South America", publicada em janeiro de 1852 originalmente no jornal The National Era, fonte da maioria das notícias sobre o Brasil para Douglass, trazia informações de um viajante que havia passado pelo império brasileiro em 1851. A matéria apareceria no The Frederick Douglass Paper em fevereiro de 1852, novamente com título modificado, agora certamente para causar mais impacto Slave trade and slavery in Brazil. ${ }^{15}$ 
A matéria descreve um país cuja disposição para abolir o tráfico e a escravidão se manifesta desde a independência de Portugal, portanto não necessitando das pressões de um movimento abolicionista, mencionado como ainda "insignificante e quase sem influência". As leis antitráfico de 1831 e 1850 são citadas como marcos que demonstram o interesse pelo fim desse comércio, mas também da escravidão. Entre aqueles que apoiavam o fim do cativeiro estavam membros do governo, médicos, membros da nobreza e das elites imperiais, os quais não eram vítimas da violência dos seus opositores, segundo a matéria, que em seguida afirmou com ironia "ao contrário da tão iluminada nação dos Estados Unidos”. O número de negros no Brasil, uma grande maioria em relação aos brancos, fato que gerava temor e motivava debates sobre políticas de deportação dos libertos nos Estados Unidos, era outro aspecto que fazia do império brasileiro um exemplo de sociedade multirracial, vejamos:

A população do Brasil consiste, aproximadamente, em um milhão e quinhentos mil brancos, um milhão e quinhentos mil índios, a maioria deles selvagens, um milhão e quinhentos mil negros livres, a maioria mulatos, e três milhões e meio de escravos, a maioria negros, totalizando juntos, oito milhões de almas, ou quase isso. $\mathrm{O}$ medo que os negros, se libertos, vai superar a raça branca, ou se tornar um fardo para eles, não parece ser considerado algo tão sério como objeção à emancipação neste país, onde há três brancos para cada sete negros, sem contar aqueles que são livres, comparado conosco (Estados Unidos) onde são vinte brancos para cada três negros homens nesse país (Brasil) não aceitam a teoria da Carolina do Sul das benção da escravidão e eles também rejeitam a outra doutrina, tão forte entre nós, da impossibilidade de uma abolição pacífica. Assim, enquanto a capital dos Estados Unidos está legislando sobre a expulsão dos negros livres do seu território, o Brasil está refletindo somente sobre a expulsão dos escravos. ${ }^{16}$

Notadamente, em 1852, representar o império do Brasil como disposto a abolir o tráfico e a escravidão era uma estratégia narrativa do movimento abolicionista, aqui estrategicamente empregada por Douglass. A mistura racial também seria mais uma vez citada como elemento que pudesse explicar a disposição do brasileiro para a liberdade e a não rejeição ao convívio com pessoas negras, inclusive na condição de livres, reforçando assim aquilo que Douglass já vinha defendendo que era a excepcionalidade do preconceito, um sentimento dos Estados Unidos.

Outro sério obstáculo para a disseminação dos princípios antiescravistas nos Estados Unidos é muito menos presente no Brasil, que é o sentido de casta e a antipatia dos brancos de se misturar ou se associar aos negros. Neste país, a mistura de raças e a mistura de cores já fez muito para nivelar este impedimento com a aceitação da emancipação. Como consequência natural é digno de nota que a incapacidade da raça negra de compartilhar com o branco os deveres e privilégios da cidadania livre é um dogma que vem desaparecendo da experiência do país. ${ }^{17}$ 
Embora o autor do texto reconhecesse que alguns obstáculos existissem para a abolição, que era o temor das pessoas acostumadas com o trabalho escravo de não conseguirem mão de obra livre suficiente, esse problema parecia um empecilho frágil diante da suposta disposição e lento processo de abolição supostamente em curso no Brasil desde 1851. Na realidade, sabemos que nesse período ainda estava longe do decreto da abolição, no entanto as impressões do viajante reforçavam as intenções de Douglass que era, no seu discurso, isolar os Estados Unidos escravistas de outras nações americanas, as quais se acreditava eram mais atrasadas. $\mathrm{O}$ trecho final do texto era perfeito para esse objetivo e foi republicado, também, na íntegra pelo abolicionista. Nele, especulou-se que era possível que o império do Brasil abolisse a escravidão antes dos Estados Unidos:

Não parece impossível que o jovem Império do Brasil possa liderar nossa vangloriada nação anglo-saxã nos trabalhos pela emancipação e que a terra de Washington, de Adams e de Jefferson possa cair na distinção singular de ocupar o último lugar entre as nações civilizadas que aboliram a instituição da escravidão. ${ }^{18}$

Contudo, Douglass temia que os projetos imperialistas de expansão da escravidão encabeçados pelos estados escravistas do sul impedissem a continuação desse processo de abolição, que ele acreditava estar em curso não só no Brasil, mas também em Cuba. Essas preocupações foram expostas em um dos seus artigos publicados no Frederick Douglass Paper, em 1854, mesmo ano de aprovação do Kansas Nebraska Act. O texto, que tinha como título "Cuba", revelava o plano de setores escravistas dos Estados Unidos de invadir a ilha e declarar guerra contra a Espanha, sob o argumento de impedir que a ilha se tornasse um "segundo Haiti". Douglass conseguia prever desde então um conflito separatista, como de fato se concretizou sete anos depois com a deflagração da Guerra Civil, e a importância do Caribe e do Brasil para o poder do sul escravista, no caso de um desmembramento da união:

Eles (os escravistas) já fixaram seus olhos sobre o rico Vale da Amazônia, promovendo explorações naquela região, estabelecendo usos peculiares com trabalho escravo e buscando estabelecer relações intimas com o governo do Brasil... o que eles realmente querem é um ponto de apoio no Vale, em que ganhos imensos serão garantidos com uso de trabalho escravo na produção de algodão, café e açúcar. O tráfico de escravos tem sido, de fato, suprimido no Brasil - as pessoas são indolentes - não há preconceito de casta ou de cor em relação aos escravos, as tendências são de enfraquecimento e total erradicação desse sistema. Uma pequena infusão de energia anglo-americana investida no poder escravista, talvez suprima essas tendências e traga o Brasil dentro da linha do Império escravista desse país. ${ }^{19}$

Douglass tinha razão nas suas especulações. Desde 1840, o capitão da marinha Americana Mathew Fountaine Maury rondava o Vale Amazônico com a intenção de anexa-lo ao sul dos Estados Unidos, empregando mão de obra escravizada e também de libertos afro-americanos que seriam deportados para 
aquela região. De acordo com Maury, aquela parte do Brasil deveria estar sob o controle dos Estados sulistas, uma vez que a Amazônia estava mais próxima de estados sulistas como Mississipi e Flórida do que do Rio de Janeiro. A ocupação do Vale Amazônico também resolveria um problema racial, transferindo parte da população negra dos Estados Unidos para um outra região distante, suspendendo o risco de um dia se tornarem maioria no país, e obviamente, da mistura racial (Machado, 2018, p.27-33).

Na década de 1850, outros temas preocupavam Douglass, e o Brasil ainda lhe servia para contrapô-los à realidade estadunidense. Em 1857 o Dred Scott Case significou um golpe duro sobre a comunidade afro-americana, sobretudo aquela livre, que vivia na região Norte. Dred Scott requereu sua liberdade na corte após viver cinco anos como homem livre no estado de Illinois e Minnesota. O chefe de justiça responsável pelo caso, um ex-senhor de escravos, declarou que Scott não era um cidadão por ser um homem negro, e que, portanto, não tinha nenhum direito ante uma corte federal (Blight, 2018, p.277). Essa lei, ao mesmo tempo que aumentou ainda mais o desamparo legal e social da população negra que vivia na região Norte, também marcou um endurecimento do discurso abolicionista. A pauta dos direitos dos afro-americanos tornou-se ainda mais fortalecida e o exemplo do Brasil, com seus libertos que eram considerados cidadãos desde a Constituição de 1823 , teve um papel fundamental no discurso.

Em maio de 1858, durante um discurso intitulado "Cidadania e o espírito de casta", Frederick Douglass usou o Império brasileiro novamente para responder à proibição imposta à população negra de Nova York de utilizar o transporte público ou fazê-lo sob a condição de não o dividir com pessoas brancas. Essa era uma das várias leis segregacionistas empregadas na região e que marcavam a experiência dos libertos com episódios de racismo e violência. Além disso, à medida que os libertos abolicionistas exigiam mais direitos e reivindicavam a condição de cidadãos, mais esses conflitos se acirravam. O discurso foi ouvido pela comunidade negra seguidora da Shiloh Presbyterian Church e, mais tarde, publicado em outros jornais, como o próprio The Frederick Douglass Paper. Enfatizando o absurdo da necessidade de cidadãos livres reivindicarem os mais simples direitos, como o de utilizar o transporte público, Douglass afirmou que isso era resultado do espírito de casta gerado, excepcionalmente, pela escravidão norte-americana.

Douglass continuou seu discurso atribuindo o atraso da população negra que vivia no Norte dos Estados Unidos às imposições legais e ao desrespeito à sua liberdade e cidadania, o que aproximava as políticas vigentes nessa parte do país àquelas empregadas no sul escravista. Assim, através desse discurso, ele combatia dois argumentos frequentemente utilizados por grupos antiabolicionistas: a inferioridade da raça negra e o atraso natural dessa "espécie". Mais uma vez, no mesmo discurso, o abolicionista cita o Brasil como exemplo de nação mais democrática do que os Estados Unidos, a despeito das premissas frequentes 
de que era um país mais atrasado por ser miscigenado, latino-americano, tropical e católico:

Eu duvido que já tenha existido um povo mais subjugado, mais desavergonhadamente massacrado e maliciosamente usado do que as pessoas livres de cor dos Estados Unidos. Mesmo em um país católico como o Brasil - um país que nós, com nosso orgulho, estigmatizamos como semibárbaro - não trata as pessoas de cor, sejam livres ou escravos, da forma injusta, bárbara e escandalosa como tratamos. As consequências dessa diferença são melhor vistas na condição do homem livre de cor lá, que vive melhor do que os daqui. A prática do país é que, quando um escravo é emancipado ele é de uma só vez investido de todos os direitos de um homem - feito igual em todos os outros aspectos do Império. Ele é um homem livre. Sua cor e suas características deixam de importar frente à chama da sua liberdade. (Blassingame, 1985, p.211-12)

Para fortalecer o argumento de que os Estados Unidos eram a única ou a nação mais racista do mundo atlântico, Douglass elevou o Brasil à categoria de país onde a liberdade de pessoas libertas era plenamente reconhecida e respeitada. Com isso, ele fazia o contraponto com a denúncia de sua fala anterior, sobre a restrição do acesso ao transporte público imposta à população negra de Nova York. Questionamos, novamente, qual seria a fonte de informação do abolicionista afro-americano. O historiador John Blassingame traz um importante indício ao afirmar que Douglass podia ter tido acesso à obra Brazil and the Brazilians, dos viajantes Kidder e Fletcher, além de Life in Brazil, de Thomas Ewbank. Na primeira obra, principalmente, as relações raciais no Brasil são descritas como igualitárias. Difundir tal imagem sobre o Brasil fortalecia a denúncia da discriminação racial arraigada nas relações raciais do vizinho norte-americano (Kidder; Fletcher, 1857; Ewbank, 1856).

Douglass também citou o exemplo dos mulatos brasileiros e como suas habilidades e intelectualidade afloravam quando encontravam um ambiente de incentivo e estímulo, o que só era possível quando não encontravam restrições à sua cidadania. Ele citou o exemplo do proprietário de uma importante tipografia no Rio de Janeiro que, segundo ele, era um homem de cor. Certamente ele estava se referindo a Paula Brito, também citado em outros jornais abolicionistas que utilizaram a mesma fonte produzida por Kidder e Fletcher. Por fim, Douglass conclui seu protesto afirmando o seguinte:

Se o homem de cor pôde se elevar da degradação à respeitabilidade no Brasil, com o mesmo tratamento nós também podemos nos elevar aqui. Se ele pode ser estimado como um homem pelo português, ele também pode ser tão estimado pelos anglo-saxões e celtas. Se ele pode obter justiça das mãos dos católicos, por que não também das mãos dos protestantes? ${ }^{20}$

Novamente, a experiência de outros povos negros da diáspora, como os afro-brasileiros, era aproximada da experiência dos afro-americanos e reforçava a ideia de que os povos negros de ambos os países compunham um só povo. 
Dessa forma Frederick Douglass imprimia seus valores de cidadania como um direito reconhecido aos libertos nascidos no Brasil, o que não acontecia com os negros estadunidenses, o que só aconteceria em 1868. Para esse abolicionista, isso se devia ao fato de o preconceito de cor presente no ideal de nação estadunidense ser o maior obstáculo para o acesso à direitos e inserção social dele e de seus pares.

\section{A década de 1860 e o Brasil na imprensa estadunidense: deportação dos libertos, o remédio contra a mistura racial}

$\mathrm{Na}$ década de 1860 , o projeto de expatriação dos afro-americanos ressurgiu reformulado no contexto da Guerra Civil e dos debates em torno do pós-abolição. Com a vitória do presidente Lincoln, a abolição da escravidão se tornava cada vez mais real dadas as suas posições consideradas moderadas por seus opositores. O presidente deixava claro que a emancipação se daria concomitantemente à deportação da população liberta. Segundo ele, a expatriação da população negra evitaria as consequências negativas da emancipação dos escravos: a amalgamação racial, a africanização da América e o negrismo livre (Horne, 2010, p.155-83, 251).

Frederick Douglass respondeu a essa iniciativa se apropriando do exemplo de império brasileiro. Em outubro de 1862, o país foi citado, dessa vez no contexto dos debates sobre a expatriação no seu jornal, o Douglass Monthly. Na ocasião, Douglass respondia às afirmações do general Montgomery Blair, aliado do presidente Lincoln, que defendia que os negros emancipados após a Guerra Civil deveriam ser expatriados para a América Central. ${ }^{21}$

Frederick Douglass respondeu ao general prezando suas afirmativas positivas, uma vez que Blair dizia que apoiava a deportação dos afro-americanos, mas não porque acreditava na inferioridade desses em relação aos brancos. Depois de saudar o general por ele crer na igualdade entre as raças, Douglass reafirmou sua defesa do direito da população negra de permanecer nos Estados Unidos, a despeito das ideias de expatriação, reafirmando sua crença numa sociedade multirracial, nos Estados Unidos.

Eu não vejo nada na natureza que confirme a diferença entre as duas raças que impeça a convivência pacífica e feliz [de brancos e negros] no mesmo país, sob o mesmo governo. Nós somos americanos de nascimento e formação e temos preferência por instituições americanas àquelas de qualquer outro país. O fato de desejarmos permanecer aqui é natural para nós e eu repito, eu não vejo necessidade para a separação. ${ }^{22}$

Além de questionar as ideologias racialistas que estavam por trás do projeto de deportação e reafirmar o direito de permanecer nos Estados Unidos, Douglass insistiu na afirmação do direito de autogoverno como algo inerente à liberdade. O fato de que os libertos no Brasil tinham o "direito" de permanecer no país em que nasceram interessava bastante ao debate político travado pelo abolicionista, que desejava mostrar, novamente, a intensidade e rigidez das re- 
gras de segregação racial no seu próprio país. Assim, fazendo uma comparação direta das sociedades brasileira e norte-americana e das relações raciais que operavam em ambas, ele escreveu:

Por que os americanos devem ser menos tolerantes em relação às diferenças nacionais de formas, características e cor da pele do que outras nações de raça branca, que em muitos outros aspectos são muito menos iluminados do que nós? Por que é que nós não ouvimos falar em projetos para se livrar de as pessoas de cor livres em Cuba ou no Brasil? Neste último país, onde há mais de quatro milhões de escravos negros, o homem livre de cor não é sujeito à expatriação... Por que não deve existir a mesma facilidade aqui? O brasileiro branco é tão branco quanto o americano branco e o negro no Brasil é tão negro quanto o homem negro aqui. Qual é a diferença? Será que o protestantismo é menos tolerante às diferenças nacionais do que o catolicismo? São as repúblicas menos liberais do que as monarquias? ${ }^{23}$

Mais de vinte anos depois dessa publicação, Douglass continuaria sua incansável luta contra a emigração dos afro-americanos para outras localidades, fosse no Caribe, fosse na América do Sul, fosse pelo clima ou pelas relações raciais mais favoráveis. Em 1888, no mês de maio, poucos dias antes do decreto do fim da escravidão no Brasil, o abolicionista não teria mais dúvidas, como já havia chegado a pensar, de que o império não se adiantaria em relação aos Estados Unidos, abolindo a escravidão antes da "América". Àquela altura, internacionalmente, o Brasil amargava a posição de última nação escravista das Américas, talvez deixando de ser uma referência para Douglass. Enquanto isso, o abolicionista continuaria a insistir na importância de que a comunidade afro-americana se mantivesse nos Estados Unidos e não se convencesse dos "benefícios" da imigração para o Caribe e nem para o Brasil, ponderando que os obstáculos com uma língua desconhecida e modos de vida que os afro-americanos não entenderiam os colocariam em uma situação de pobreza muito pior do que no seu país de origem. Douglass torcia para que a comunidade negra não fosse convencida por tais promessas e pelo esquema, que tinha como premissa, a hegemonia racial branca no seu país. ${ }^{24}$ A luta por direitos iguais nos Estados Unidos seria longa, de modo que Douglass, que faleceu em 1895, deixaria seu legado à maioria dos afro-americanos que permaneceram no país e levaram a cabo seu projeto de sociedade multirracial igualitária, que até hoje, a despeito das conquistas, ainda está por se concretizar.

\section{Notas}

1 Agradeço às/aos colegas da linha de pesquisa "Escravidão e invenção da liberdade", da Universidade Federal da Bahia, que contribuíram com a versão final deste artigo.

2 Sobre a Escola Americana de Etnologia ver: Gould (1996, p.71); Stanton (1960, p.557).

3 Frederico Douglass. Gazeta da tarde, 25 de abril de 1883. 
4 Neste texto não traduzo o termo nigger para manter significado e valor simbólico do termo no contexto dos Estados Unidos. Acredito que traduzir nigger para negro deslocaria o contexto e o significado da palavra nos Estados Unidos do século XIX.

5 The New York Times, Frederick Douglass on the war, 13 de fevereiro de 1862, p.8

6 Americanos neste texto, tal como descrito por Smith, está sendo tratado como sinônimo de estadunidense.

7 Sobre poligenismo, ver também Gould (1996, p.71).

8 Sobre o assunto, ver Brito (2014, p.31-8).

9 “The Brazilians", in: Friend's Review: a religious, literary and miscellaneous jornal, 28 de abril de 1849, p.509 - os grifos no texto são meus.

10 Discuto amplamente como a imprensa negra estadunidense apropriou e utilizou o exemplo do Brasil escravista no discurso abolicionista em Brito (2014, cap.2).

11 Uma pequena biografia do diplomata Joaquim Tomás do Amaral pode ser encontrada em: <https://cpdoc.fgv.br/sites/default/files/verbetes/primeira-republica/AMARAL,\%20Joaquim\%20Tom\%C3\%Als\%20do.pdf $\geq$ Acesso em: 7 jun. 2019.

12 Sobre as políticas raciais no Brasil, onde a mistura racial era um caminho escolhido para a homogeneização e embranquencimento da população, o que aconteceu também em outros países latino-americanos, ver Andrews (2014).

13 O episódio é narrado por David Blight (2018, p.204).

14 Essa frase de Frederick Douglass é citada em Johnson (1933, reprint 1973, p.61).

15 The Frederick Douglass Paper, 19 fev. 1852. The National Era, em janeiro de 1852.

16 The Frederick Douglass Paper, 19 fev. 1852.

17 The Frederick Douglass Paper, 19 fev. 1852.

18 The Frederick Douglass Paper, 19 fev. 1852.

19 Cuba. Frederick Douglass Paper, 24 de março de 1854

20 Discurso de Frederick Douglass citado em Blassingame (1985, p.212).

21 Douglass Monthly, out. 1862.

22 Douglass Monthly, out. 1862.

23 Douglass Monthly, out. 1862.

24 Should the negro stay? The Washington Post, 5 maio 1888.

\section{Referências}

ALEXANDER, L. The Black Republic: the influence of Haitian revolution on northern black political Consciousness, 1816-1862. In: JACKSON, M.; BACON, J. African Americans and the Haitian revolution: select essays and historical documents. New York: Routledge, 2010. p.57-8.

ANDREWS, G. R. America Afro-latina. São Carlos: UfsCAR, 2014.

BLASSINGAME, J. W. (Ed.) The Frederick Douglass Papers. Series one: speeches, debates and interviews. v.3: 1855-63. New Haven; London: Yale University Press, 1985. BLIGHT, D. Prophet of freedom. New York: Simon and Schuster, 2018. 
BRITO, L. da C. Impressões norte-americanas sobre escravidão, abolição e relações raciais no Brasil escravista. São Paulo, 2014. Tese (Doutorado) - Faculdade de Filosofia, Letras e Ciências Humanas, Universidade de São Paulo. São Paulo, 2014.

O crime da miscigenação: a mistura de raças no Brasil escravista e a ameaça à pureza racial nos Estados Unidos pós-abolição. Revista Brasileira de História, São Paulo, v.36, n.72, p.108, 2016.

DOUGLASS, F. The narrative of life and times of Frederick Douglass. (1845) Illinois: Lushena Books, 2000.

My boundage and my freedom. 1855. Introdution and notes by David Blight. New Haven: Yale University Press, 2014.

EWBANK, T. Life in Brazil; or, a journal of a visit to the land of the cocoa and the palm. New York: Harper and Brothers, 1856.

FREDRICKSON, G. M. The black image in the white mind: the debate on afro-american character and destiny, 1817-1914. New York: Harper and Row Publishers, 1971.

GOULD, S. J. The mismeasure of man. New York: W. W. Norton \& Company, 1996.

HOLT, T. Children of fire: a history of African-Americans. New York: Hill and Wang, 2010.

HOOKER, J. Theorizing race in the Americas: Douglass, Sarmiento, Du Bois e Vasconcelos. New York? Oxford University Press, 2017.

HORNE, G. O Sul mais distante: os Estados Unidos, o Brasil e o tráfico de escravos africanos. São Paulo: Cia. das Letras, 2010.

JOHNSON, J. W. Along this way. New York: 1933 (reprint 1973), p.61.

KIDDER, D. P.; FLETCHER, J. C. Brazil and the Brazilians, portrayed in historical and descriptive sketches. Philadelphia: Childs and Peterson, 1857.

LEMIRE, E. Miscegenation: making race in America. Philadelphia: University of Pennsylvania Press, 2002.

MACHADO, M. H. Raça, Ciência e viagem no século XIX. São Paulo: Intermeios, 2018.

NOTT, J. C. Unity of human race. The Southern Quartely Review, jan. 1846, p.1.

NWANKWO, I. K. Black cosmopolitanism: racial consciousness and transnational identity in the Nineteenth-Century Americas. Philadelphia, Pennsylvania: University of Pennsylvania Press, 2005.

PRICHARD, J. C. The Natural History of Man: Comprising Inquiries Into the Modifying Influence of Physical and Moral Agencies on the Different Tribes of the Human Family. New York: H. Bailliere Publisher, 1855.

SANTOS, A. A. Projeções do "eu” e identidades nas narrativas dos abolicionistas Luiz Gama e Frederick Douglass. São Paulo, 2014. Dissertação (Mestrado) - Faculdade de Filosofia, Letras e Ciências Humanas, Universidade de São Paulo. São Paulo, 2014.

SLENES, R. W. A. A “Great Arch” Descending: Manumission Rates, Subaltern Social Mobility and Enslaved, Freeborn and Freed Black Identities in Southeastern Brazil, 1791-1888. In: GLEDSON, J.; SCHELL, P. A. (Ed.) New Approaches to Resistance in Brazil and Mexico. Durham: Duke University Press, 2012. p.100-18. 
STANTON, W. The leopard's spots: scientific attitudes toward race in America 18151859. Chicago: University of Chicago Press, 1960.

RESUMO - Esse artigo discutirá as impressões do abolicionista estadunidense Frederick Douglass sobre as relações raciais no Brasil escravista. Para tanto, utilizaremos sua autobiografia My bondage and my freedom, em cruzamento com artigos e discursos de sua autoria, nos quais o abolicionista revela o seu olhar comparativo entre a vida dos negros estadunidenses e afro-brasileiros. Nossa abordagem dará ênfase ao tema da mistura racial, um dos aspectos que mais chamavam a atenção de Douglass sobre o Brasil. Isso porque o tema tanto respondia a um dilema pessoal, já que ele mesmo era um homem de origem birracial, quanto pelo fato de o Império lhe parecer um exemplo de sociedade multirracial e igualitária que tanto sonhava para os Estados Unidos.

PALAVRAS-CHAVE: Frederick Douglass, Abolicionismo, Brasil.

ABSTRACT - This article will discuss the impressions of the American abolitionist Frederick Douglass of race relations in Brazilian slave-ridden society. To do so, we will use his autobiography My bondage and my freedom, together with articles and speeches he wrote, in which his abolitionist eyes reveal a comparative approach between the lives of African-Americans and Afro-Brazilians. We will emphasize the subject of racial mixing, one of the aspects that most drew Douglass's attention to Brazil, both because it was a personal dilemma for him, being himself was a man of biracial origin, and because the Empire seemed to him an example of a multiracial and egalitarian society that he very much dreamed for the United States.

KEYWORDS: Frederick Douglass, Abolitionism, Brazil.

Luciana da Cruz Brito é professora do Colegiado de História da Universidade Federal do Recôncavo da Bahia (UFRB). @ - lucianabrito@ufrb.edu.br https://orcid.org/0000-0001-8426-0552

${ }^{\text {I } U n i v e r s i d a d e ~ F e d e r a l ~ d o ~ R e c o ̂ n c a v o ~ d a ~ B a h i a, ~ C a c h o e i r a, ~ B a h i a, ~ B r a s i l . ~}$

Recebido em 10.6.2019 e aceito em 21.6.2019. 